\title{
A monstrous growth: An historical note on carcinoma of the scrotum
}

\author{
M. D. KIPLING, R. USHERWOOD, and R. VARLEY \\ H.M. Medical Inspectorate, the Department of Classics, Warwick School, \\ and Coventry and Warwickshire Hospital
}

'You will find it a very good practice always to verify your references, Sir.'

Memoir of Dr Routh, 1755-1854.

The first description of carcinoma of the scrotum has been ascribed to Bassius by several authors whose example was followed by Kipling (1969). The reference, thus copied, was to the Tenth Observation, 'Scrotum sphacelo consumptum et fenatum', in the Anatomical, Surgical and Medical Observations of Heinrich Bass (Bassius) published in 1731.

One of us (M.D.K.) has recently been able to consult in the British Museum the only available copy of this work in Great Britain, a copy that has lain in the shelves with leaves uncut for the past two hundred years.

Observatio $\mathrm{X}$ on 'A case of spongy scrotum, entirely destroyed and regenerated' may be translated in abbreviated form from the Latin as follows:

\footnotetext{
'With wonder we especially observed the skill of nature in repairing those parts of the body which had been unfortunately destroyed by the formation of a new layer of growth. And this very thing we observe in the scrotum, as when affected by ascites a healthy scrotum becomes oedematous and altered by the excess of fluid into a decaying spongy mass and becomes necrotic. A new covering grows in place of the former and will once again serve as a protection for the exposed testicles; just as has been noted by other authors and ourselves in the case of Johanne Gohlen, a man 40 years old in 1719 .

This man, some weeks before, had contracted a benign urethritis by unseasonable intercourse with his wife, who was suffering from a transient white flux, at a time when this was suppressed. He was immediately seized by a lacerating and prolonged pain at the root of the penis, and after the space of eight days there developed a small swelling in the perineum, associated with redness and pain; to this suppuration the surgeon applied a soothing
}

poultice, too hastily, so that he burned the scrotum in such a way that inflammation rapidly supervened, developing into a spongy mass, accompanied by fever, high temperature, terrible thirst and delirium.

Meanwhile, the sick man had given instructions for me to be summoned, urgently begging for help. Upon examining the scrotum, which was now spongy and necrotic and partially freely detached on each side, I removed the necrotic portions, leaving the healthy remnants and some of the necrotic tissues. Both testicles lay bare, also some of the Tunica Vaginalis remained intact and apparently healthy and unaffected by necrosis.

With the intention of healing the denuded area I applied ointment and plaster. Using these measures, within a few days the fever dispersed, and after application of the external remedies the spongy mass became reduced and separated. Afterwards new healthy fleshy fibres developed, completely covering the testicles. Thus, with the scrotum destroyed, a comparable covering grew, as by a miracle, so that within four weeks the sick man not only regained a scrotal covering, but went away fully restored.'

We consider that the clinical condition described is suggestive of perineal abscess formation with sinuses leading to the scrotum (watering-can scrotum) rather than of a scrotal neoplasm.

If this opinion is accepted, it would seem that the first description of carcinoma of the scrotum might be attributed to Treyling (1740) and, if one accepts service in the cavalry as an occupational risk, his Observatio CXXX, 'Scrotum immaniter auctum scirrhoso scrophulosum', might be thought to have priority over that of Percival Pott as the first account of occupational cancer of the scrotum.

\section{A case of monstrous scirrhous-like} scrotal growth

'The planet Mars is an angry planet, but more angry 
when it is in conjunction with Venus, venting its wrath upon the vital organs of its own subjects. Thus, for example: Gregorius Bergmayr, a cavalryman of the Bavarian Army, 36 years old, who had campaigned strenuously under both planets, had been clumsily treated for gonorrhoea by a camp surgeon, and had cut off his own penis with an ordinary knife right up to the pubic hair, as it was infected with a terrible sore. He healed the wound by the close application of plasters to such an extent that he was able once more to continue military service, and could pass urine both freely and in spurts. Now it chanced that he was once attempting to jump on horse-back over too wide a ditch, and by knocking his scrotum against the point of the saddle (Fig. 1) he severely bruised it. As a result, apart from the terrible pain, the scrotum gradually began to swell noticeably and became inflamed; and because of unsuitable treatment by barbers and wise women, finally developed a hard tumour of the thickness of two fists. Though the colouring of the skin remained unchanged, the scrotum began to develop multiple swellings, marked here and there with deep folds, like so many fatty tumours. (After dissection it was shown to be composed of this fatty substance.) These began to harden (Fig. 2).

Growing at last impatient with the pain, and fearingnot without cause - the danger of cancer, he chanced to meet an itinerant practitioner, and since he believed that this man had practised with some success in other instances, he begged him to remove his scrotum. After examination, the practitioner, astonished at this unusual case, and not daring to embark upon so dangerous an operation, referred him to me for my opinion.

I examined the poor wretch, and since in other respects he was a vigorous, active and sensible man, and as in the hope of living a more comfortable life afterwards, or at least of a death preferable to this miserable life, he had not hesitated to submit himself voluntarily to operation, I strongly advised this amputation, passing on instruction to the surgeon that he should first of all make a vertical incision, as near as possible to the middle of the scrotum,

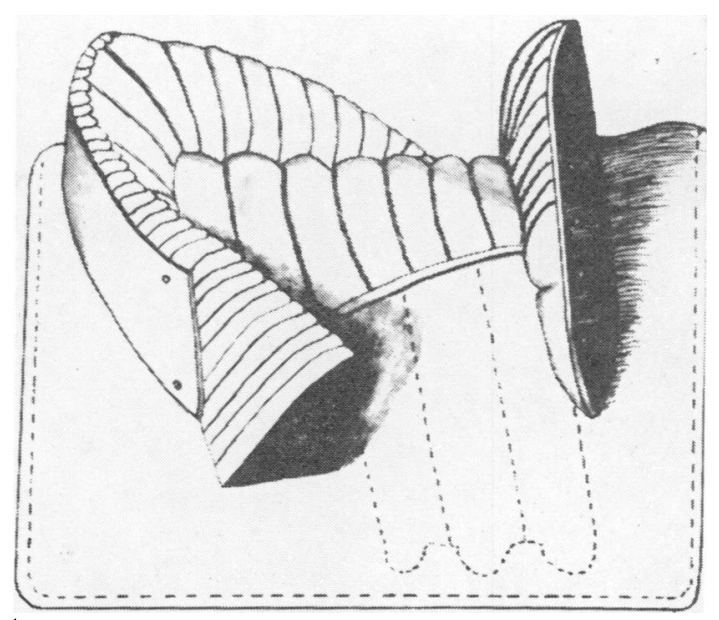

FIG. 1. Eighteenth century military saddle.

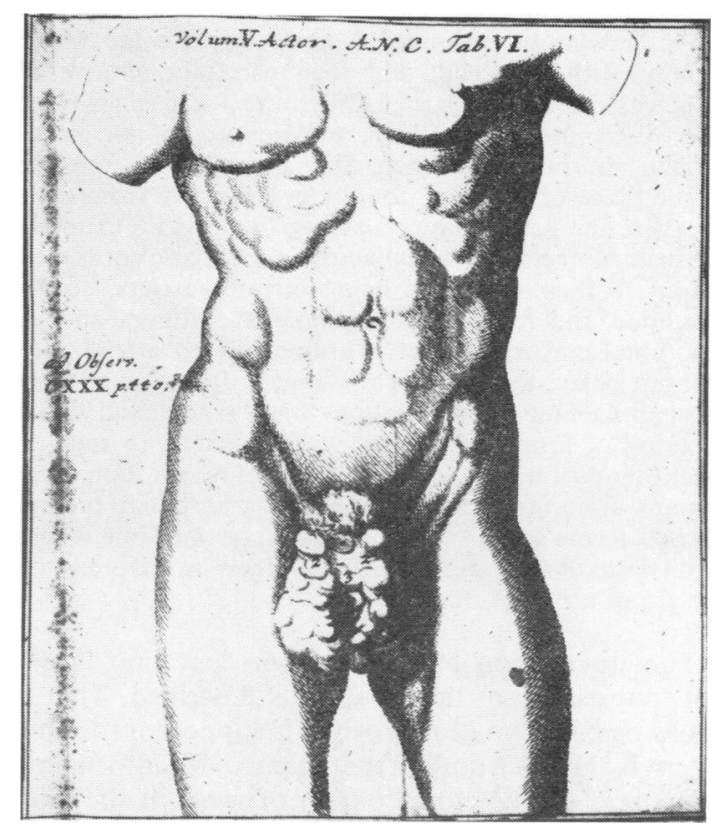

FIG. 2. Gregorius Bergmayr.

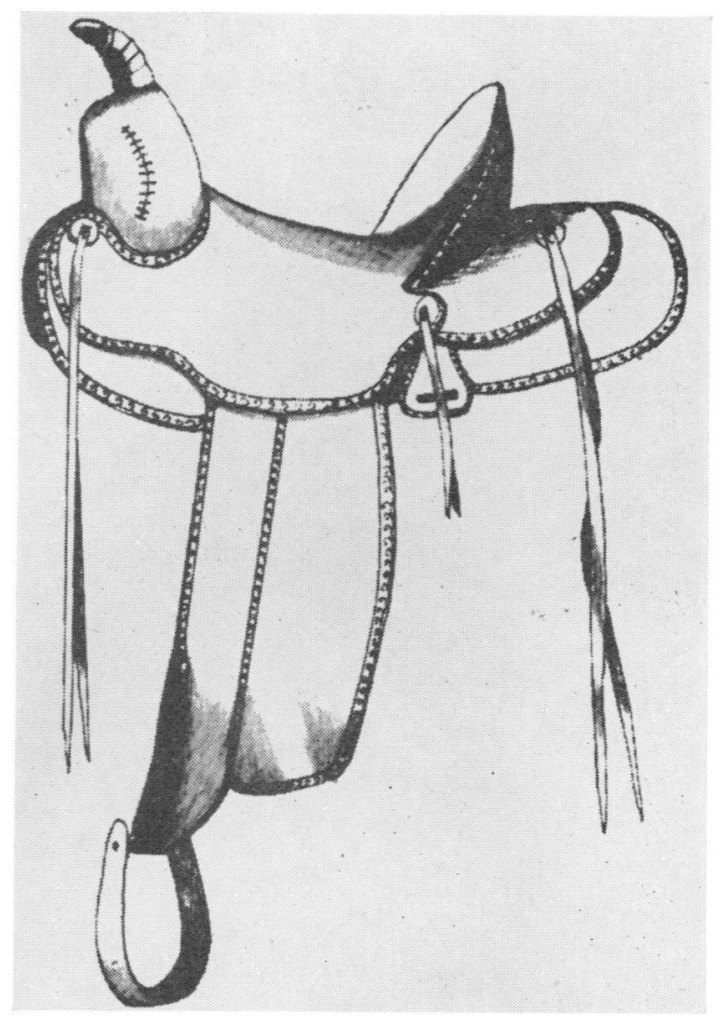

FIG. 3. Mexican-type saddle. 
to determine the condition of the testicles-which could not otherwise be examined - next to ligate the whole tumour with a thread, and then carefully remove it. This was carried out successfully, and the testicles were discovered and pushed back undamaged to the groins in their natural state. When, after three days, I returned to the place of business, four hours' journey from here, to where the patient lay, on seeing the testicles exposed, I instructed the surgeon to ligate the spermatic cords, and amputate them both, as being already useless, to his manhood and for the propagation of children, and an emotional embarrassment; warning him to attend to it without delay, in view of the danger of gangrene. After this I applied remedies of Balsam to the wound, and within a period of four weeks it healed completely, to such an extent that soon he was able to come to me on foot, without any discomfort, and with joy and gratitude to present himself to me cured (if we may thus speak of one whose virility was lost), passing urine as freely as before, with the aid of a funnel-shaped cane.'

The description and illustration leave no doubt but that cancer of the scrotum is described. That it could be of occupational origin is supported to some extent by Henry's finding that many of his informants laid stress on the close contact of some of the fatal cases with horses, including especially a Colonel whose hobby was horse riding (Henry, 1946) and by the occurrence recently of a fatal case in a retired officer of the Royal Horse Artillery in the Birming- ham region who had served in the ranks for seven years and as an officer for four years. Stronger support to a belief in an occupational factor is provided by the report of an increased incidence in muleteers in Mexico, who, like the Bavarian cavalryman, use a high pommelled saddle (Fig. 3) (Carteaud, 1964).

We are deeply indebted to Dr. W. N. Scott and the Staff of the Library of Queen's University of Belfast for the reproduction of Fig. 2, and to Messrs. Harper \& Row, New York, for permission to reproduce Figs. 1 and 3 from 'Man on Horseback' (1964) by Glenn R. Vernan. We are also grateful to the Trustees of the British Museum, to Dr. M. A. Dobbin Crawford and Dr. K. Biden-Steele of the Ministry of Defence, and to Dr. D. L. P. de Courcy and Dr. J. A. H. Waterhouse.

\section{References}

Bassius, H. (1731). Observationes anatomico-chirurgico-medicae, p. 193. Halde Magdeburgicae.

Burgon, J. W. (1878). Memoir of Dr. Routh. Quart. Rev., 146, 1-39. Carteaud, A. (1964). la Presse méd., 72, 3355.

Henry, S. A. (1946). Cancer of the Scrotum in relation to Occupation. p. 71. Oxford University Press, London.

Kipling, M. D. (1969). Oil and carcinoma of the scrotum. Trans. soc. occup. Med., 19, 36 .

Treyling, J. (1740). Acta Acad. Nat. Curios., Nuremberg, 5, 440

Received for publication February 23, 1970 